(c) Cambridge University Press 2012

\title{
Some like it hot: Paracartia grani (Copepoda: Calanoida) arrival in the Thau lagoon (south of France-Mediterranean Sea)
}

\author{
Severine Boyer ${ }^{1}$, Isabelle Arzul ${ }^{2}$ and Delphine Bonnet ${ }^{1, *}$ \\ 1 Laboratoire d'Ecologie des Systèmes Marins Côtiers, UMR5119, Université Montpellier 2, Place Eugène \\ Bataillon, CC 093, 34095 Montpellier Cedex 05, France \\ ${ }^{2}$ Laboratoire de Génétique et Pathologie de l'IFREMER, BP 133, 17390 La Tremblade, France \\ *: Corresponding author : Delphine Bonnet, email address : delphine.bonnet@univ-montp2.fr
}

\begin{abstract}
:
Paracartia grani originates from high latitudes and has progressively been recorded in the Mediterranean Sea since the 1980s. In Thau lagoon, while Acartia clausi and Acartia discaudata present maximum peaks of abundance from January to April and in November and December, both species being perennial over the year, $P$. grani and Paracartia latisetosa appear in May, develop during summer, in July and August, and slowly decrease in autumn before disappearing from the water column in December. The Acartiidae populations have changed over the years at our monitoring station. Indeed, P. latisetosa was last recorded in August 1983 while P. grani appeared in the lagoon in 1998 .
\end{abstract}

Keywords: Paracartia grani ; Mediterranean Sea ; long term changes ; Acartia spp. 


\section{Introduction}

Paracartia grani (Sars, 1904) belongs to the Acartiidae family (Copepoda Calanoida) which is the most abundant family in Thau (South of France). It was reported for the first time by Sars (1904) off Western Norway and has been observed in shelf and coastal water of the Northeastern Atlantic and North Sea (Gallo, 1981; Razouls et al., 2009). Over the last twenty years, it has progressively appeared in the Mediterranean Sea (Rodríguez \& Vives, 1984; Lakkis, 1990; Belmonte \& Potenza, 2001; Daly Yahia et al., 2004; Pane et al., 2005; Razouls et al., 2009) (Figure 1). In 1984, P. grani was recorded for the first time in the western Mediterranean, in Malaga harbour close to Gibraltar strait (Rodríguez \& Vives, 1984). It was observed 15 years later in Spanish and French coastal waters (references in Pane et al., 2005) and for the first time in Thau lagoon in 1998 (L Euzet Pers. Com.). However as this latest record was not published, it is still absent from the Thau lagoon fauna list. More recently, it has been reported in the North of the Adriatic Sea (De Olazalbal et al., 2006) and in the Aegean Sea (references in Pancucci-Papadopoulou et al., 2005). However, for the moment, there is no report of $P$. grani in the Black Sea (Belmonte \& Potenza, 2001). P. grani is also present in polluted sites such as harbours of Malaga (Rodríguez \& Vives, 1984), Barcelona and Genova (Pane et al., 2005) where it persists.

$P$. grani European biogeography was determined using a literature review as a basis to suggest hypothesis for its presence in warmer Mediterranean coastal waters. The influence of $P$. grani introduction on Thau lagoon Acartia spp. assemblages is also discussed.

\section{Methods}

\subsection{Paracartia grani sampling}

Zooplankton samples were collected twice a month between February 2008 and March 2009 at a monitoring station S1, close to Sète channel in Thau lagoon $\left(40^{\circ} 03 \mathrm{~N} ; 03^{\circ} 41 \mathrm{E}\right)$. A WP2 plankton net with a $200 \mu \mathrm{m}$ mesh size was used to carry horizontal hauls in the surface layer (maximum $1 \mathrm{~m}$ depth). Samples collected were fixed with formaldehyde to a final concentration of $4 \%$ and used to determine the biodiversity and abundance of planktonic populations at the station.

\subsection{Long term changes}

During the first half of the 20th century, several zooplankton monitoring studies have taken place at the same sampling station. However these results were never published and data were kept in the archives of the Station Méditerranéenne de l'Environnement Littoral in Sète. The main example regards the Professor Louis Euzet (Université Montpellier 2, France) who did follow the plankton population dynamics as well as temperature and salinity for his master and thesis reports in 1937 and 1938 and between 1949 and 1952 . We used his notebooks to extract the population dynamics data at these periods. It has to be specified that those data are semi quantitative as the abundances, in number of organisms per unit of volume, were not expressively specified, but the proportion of each species versus the total zooplankton was indicated. An additional study published by Lam Haoi in 1985 (Lam Haoi, 1985) was also used for a long term comparison of Acartia spp. population dynamics during the last 60 years. 
To allow a comparison between Euzet's records, Lam Haoi's study (1985) and our own data, results were all presented as percentages of a targeted species versus the total zooplankton abundance.

Temperature data were available for the years 1949, 1950, 1951, 1952, 2008 and 2009. In 2008 and 2009, salinity measurements were also done. Relationships between copepods abundance and temperature or salinity were investigated by testing the significance of the Pearson correlation coefficient.

\section{Results}

During our study in Thau lagoon (February 2008- March 2009), P. grani was detected in zooplankton samples in summer and autumn (June -December 2008 which year). During this period, the temperature ranged between $22.4^{\circ} \mathrm{C}$ in June to $8.3^{\circ} \mathrm{C}$ in December 2008 which year with a mean value of $18.0^{\circ} \mathrm{C}$.

An ecological succession of the different Acartia species can be noticed at the monitoring station, with $A$. clausi occurring in average from January until March in high abundance (ranging from $8.1 \%$ of the total zooplankton abundance in March 1950 up to $65.5 \%$ in February 2008) followed by $A$. discaudata from February to April ( highest contribution in March 2009: 36.2\%). Both $P$. grani and $P$. latisetosa appear to have their maximum abundances, $53.1 \%$ in 2009 and $13.6 \%$ in 1952 respectively, in August. A second peak of abundance ( up to $32.8 \%$ in December 2008) of $A$. clausi is observed from November to December (Figure 2).

Acartia populations have undertaken changes since the 1950ies (Figure 2). Both $A$. clausi and $A$. discaudata contribution to the total zooplankton abundance have increased over the study period. $P$. latisetosa has disappeared from the monitoring station since 1985 while $P$. grani is now encountered since 2008.

\section{Discussion}

\section{1. $P$. grani population dynamics}

$P$. grani is the most abundant Acartia species in August (2008) where it contributes up to $53 \%$ of total zooplankton $\left(2040\right.$ ind $\left.\mathrm{m}^{-3}\right)$. This peak is followed by a drastic decline and $P$. grani disappears in January (2009) as it has been reported by Rodriguez et al. (1995) who described it as the dominant Acartia species in summer in Malaga bay. Similarly, Pane et al. (2005) indicated P. grani occurrence in autumn (from September to December with a peak in October) in the Western Harbour of Genova (Ligurian Sea), supporting the results reported by Guerrero (1993) at a coastal station in the Alboran Sea. Alcaraz (1977) described P. grani as an opportunist species as it is commonly found in coastal waters but can also be spotted in brackish waters and polluted sites (Rodriguez \& Vives, 1984; Pane et al., 2005) where it persists.

\subsection{Long term changes in Acartia spp. populations}

Studies on P. latisetosa are rare (Belmonte, 1992; Belmonte, 1998; Siokou-Frangou \& Papathanassiou, 1991; Siokou-Frangou et al., 2005). However, this species is known to be encountered generally at high abundances in very confined environments with fresh waters 
inputs and especially in summer (Siokou-Frangou \& Papathanassiou, 1991). It was described in Thau until the 50ies, as abundant during summer and in low abundances in winter and spring (Fatemi, 1937; Mathias \& Euzet, 1951, 1962). Last record at our sampling station was in August 1985, in low abundance (less than 1\%) (Lam Haoi, 1985). Our monitoring station is mainly under sea water influence and consequently it does probably not represent the ideal environment for $P$. latisetosa development. However, $P$. latisetosa might still be present in Thau lagoon in areas closer to the river mouths.

In addition, $P$. grani appearance in Thau might be responsible for $P$. latisetosa drastic decrease. Indeed, its presence in the lagoon might be older than 1998, and $P$. grani is occurring during the warm period meaning that it could be occupying the same ecological niche that $P$. latisetosa. $P$. latisetosa disappearance might therefore be a consequence of a competition with $P$. grani. The fact that the latest remains in the ecosystem while the native species has disappeared might be explained by recent studies showing that non native Acartia species are able to colonize coastal areas and estuaries (Seuront, 2005; David, 2007) and that they are modifying the status of native species which are subject of competitive pressure (Lakkis, 1994).

Quantitative data on Acartia sp. showed that the species abundances are not significantly correlated with temperature or salinity in Thau lagoon between February 2008 and March 2009 ( $p>0.05$ ). Similarly, for each year of the long term series, the contributions of each species to the total zooplankton abundance are not correlated with temperature variation $(p>0.05)$. Therefore, while climate changes have been shown to modify seasonality and period of dominance of $A$. tonsa in Narragansett Bay (Sullivan et al., 2007), in Thau lagoon, changes in Acartia spp. community structure have another origin than temperature. In addition, if climate change was to be blame, it is likely that temperature would have increased, favouring the thermophile species $P$. latisetosa (Kritchagin, 1873) which is a dominant species in summer (Fatemi, 1937; Mathias \& Euzet, 1962; Lam Haoi, 1985). Surprisingly enough, $P$. latisetosa has currently totally disappeared from the plankton community at this station.

\subsection{Introduction in the Mediterranean Sea}

The introduction of Paracartia grani in the Mediterranean Sea might first be explained by a natural migration via Gibraltar strait (i.e. Yebra et al., 2011). Indeed, several studies, focused on copepods ecology, have underlined the fact that even though the Strait of Gibraltar and the Almeria-Oran Front are considered important phylogeographic barriers in many marine species there is some evidence of transport of copepods across the Gibraltar Strait and the Almeria-Oran Front and for some species, populations are not genetically differentiated between the NE Atlantic and the W Mediterranean (Tyrrhenian) based on $16 \mathrm{~S}$ data (e.g. Yebra et al., 2011). An involuntary introduction could also be the result of human activities: for example transport via ship ballast waters (Belmonte \& Potenza, 2001; Pane et al., 2005) or bivalve transfers between the Atlantic Ocean and Mediterranean Sea can be suggested as sources of introduction. However, several arguments favour the latest hypothesis:

-P. grani ecology has been closely linked with bivalve production (i.e. Ostrea edulis, Audemard et al. 2001, 2002, 2004), as it has been suggested to be one of the intermediate hosts of the protozoan paramyxean parasite Marteilia refringens responsible for marteiliosis, a major disease for bivalve production in Europe which requires mandatory notification to the OIE (the World Organisation for Animal Health) and to the EU (European Union) when detected. During the cultivation of bivalves, the organisms might be transferred several times (see details for Crassostrea gigas cycle in Mineur et al., 2007). Such transfers are permitted within the European Community and there is no obligation to report them (Mineur et al., 2007). 
-In Thau lagoon, Mineur et al.'s results (2007) support the hypothesis that oyster transfers are effective as primary and secondary vectors of macroalgal introductions.

-Many species have been accidentally introduced in association with bivalve transfers, but there is little direct evidence. As most records of $P$. grani are correlated with shell farms sites (Figure 3), we suggest that shell transfers between the Atlantic and the Mediterranean Sea might be responsible for its introduction into the Mediterranean.

\section{References}

Alcaraz M. (1977) Ecologia competancia y segregation en especies congenéricas de copépodos (Acartia). PhD Thesis, Universitad de Barcelona, Spain.

Audemard C., Barnaud A., Collins C.M., Le Roux F., Sauriau P.G., Coustau C., Blachier P. and Berthe F.C.J. (2001) Claire ponds as an experimental model for Marteilia refringens life-cycle studies: new perspectives. Journal of Experimental Marine Biology and Ecology 257, 87-108.

Audemard C., Le Roux F., Barnaud A., Collins C.M., Sautour B., Sauriau P.G., de Montaudouin X., Combes C. and Berthe F.C.J. (2002) Needle in a haystack: involvement of the copepod Paracartia grani in the life-cycle of the oyster pathogen Marteilia refringens. Parasitology 124, 315-323.

Audemard C., Sajus M.C., Barnaud A., Sautour B., Sauriau P.G. and Berthe F.C.J. (2004) Infection dynamics of Marteilia refringens in flat oyster Ostrea edulis and copepod Paracartia grani in a claire pond of Marennes-Oleron Bay. Diseases of Aquatic Organisms 61, 103-111.

Belmonte G. (1992) Diapause egg production in Acartia (Para-cartia) latisetosa -Crustacea, Copepoda, Calanoida. Bulletin of Zoology 59, 363-366.

Belmonte G. (1998) The egg morphology of 7 Acartiidae species: a preliminary survey of the ootaxonomy of calanoids. Journal of Marine Systems 15, 35-39.

Belmonte G. and Potenza D. (2001) Biogeography of the family Acartiidae (Calanoida) in the Ponto-Mediterranean Province. Hydrobiologia 453/454, 171-176.

DalyYahia M.N., Souissi S. and Yahia Kéfi O.D. (2004) Spatial and temporal structure of planktonic copepods in the Bay of Tunis (Southwestern Mediterranean Sea). Zoological Studies 43 (2), 8-19.

David V., Sautour B., and Chardy P. (2007) Successful colonization of the calanoid copepod Acartia tonsa in the oligo-mesohaline area of the Gironde estuary (SW France) - natural or anthropogenic forcing? Estuarine and Coastal Shelf Science 71, 429-442.

De Olazalbal A., Comici C. and Umani F. (2006) Prima osservazione di Paracartia grani Sars, 1904 (Copepoda: Calanoida) nel Golfo di trieste. Biologia Marina del Mediterraneo 13 (1), 964-967.

Fatemi M. (1937) Les variations saisonnières du plancton de l'Etang de Thau à l'embouchure du canal de Sète. PhD Thesis, Université Montpellier 2, France.

Gallo J.M. (1981) Les copépodes pélagiques néritiques de La Rochelle. Annales de la Société Scientifique Naturaliste de Charente-Maritime 6 (8), 847-850.

Guerrero F. (1993) Producción, estrategias reproductivas y proliferación de Acartia (Copepoda: calanoida) en sistemas costeros sometidos a distintas escalas temporales de fluctuación ambiental. PhD Thesis, Universidad de Málaga, Spain.

Lakkis S. (1990) Composition, diversité et successions des copépodes planctoniques des eaux libanaises (Méditerranée Orientale). Oceanologica Acta 16, 489-501.

Lakkis S. (1994) Coexistence and competition within Acartia (Copepoda, Calanoida) congeners from Lebanese coastal water: niche overlap measurements. Hydrobiologia 292/293, 481-490. 
Lam Hoai T. (1985) Evolution saisonnière du zooplancton dans trois sites peu profonds de Thau, une lagune Nord-Méditerranéenne. Hydrobiologia 128, 161-174.

Mathias P. and Euzet L. (1951) Sur les copépodes planctoniques de l'Etang de Thau. Bulletin de la Société d'Histoire Naturelle de Toulouse 86, 184-188.

Mathias P. and Euzet L. (1962) Le plancton du bassin de Thau (Etang des Eaux Blanches). Naturalia Monspeliensia IV, 7-28.

Mineur F., Belsher T., Johnson M.P., Maggs C.A. and Verlaque M. (2007). Experimental assessment of oyster transfers as a vector for macroalgal introductions. Biological conservation 137: 237-247.

Pancucci-Papadopoulou M., Zenetos A., Corsini-Foka M. and Politou C.H. (2005) Update of marine alien species in Hellenic waters. Mediterranean Marine Science 6/2, 1-11.

Pane L, Boccardo S, Mariottini GL (2005) Mesozooplankton assemblage and First Record of Paracartia grani Sars G.O., 1904 (Copepoda: Calanoida) in the Western harbour of Genova (Ligurian Sea). Rivista di Biologia/Biology forum 98, 323-336.

Razouls C., de Bovée F., Kouwenberg J. and Desreumaux N. (2009) Diversité et répartition géographique chez les Copépodes planctoniques marins. http://copepodes.obsbanyuls.fr

Rodríguez V. and Vives F. (1984) Copepodos de las aguas portuarias de Màlaga. Investigaciones Pesqueras 48 (2), 235-254.

Rodriguez V., Guerrero F. and Bautista B. (1995) Egg production of individual copepods of Acartia grani Sars from coastal waters: Seasonal and diel variability. Journal of Plankton Research 17(12), 2233-2250.

Sars G.O. (1904) Description of Paracartia grani, GO Sars, a peculiar calanoid occurring in some oysterbeds of western Norway. Bergens Museums Aarbog 194 (4), 1-16.

Seuront L. (2005) First record of the calanoid copepod Acartia omorii (Copepoda, calanoida: Acartiidae) in the Southern Bight of the North Sea. Journal of Plankton Research 27, 1301-1306.

Siokou-Frangou I. and Papathanassiou E. (1991) Differentiation of zooplankton populations in a polluted area. Marine Ecology Progress Series 76, 41-51.

Siokou-Frangou I., Zervoudaki S., Kambouroglou V. and Belmonte G. (2005) Distribution of mesozooplankton resting eggs in seabottom sediments of Thermaikos gulf (NW Aegean Sea, Greece) and possible effects of sediment resuspension. Continental Shelf Research 25(19-20), 2597-2608.

Sullivan B.K., Costello J.H. and Van Keuren D. (2007) Seasonality of the copepods Acartia hudsonica and Acartia tonsa in Narragansett Bay, RI, USA during a period of climate change. Estuarine Coastal and Shelf Science 73, 259-267.

Yebra L., Bonnet D., Harris R.P., Lindeque P.K. and Peijnenburg K.T.C.A (2011) Barriers in the pelagic: population structuring of Calanus helgolandicus and $C$. euxinus in European waters. Marine Ecology Progress Series 428, 135-149 


\section{Figures}

Figure 1. Biogeography (literature record) of Paracartia grani (Copepoda: Calanoid) in Europe in 2011. Records of $P$. grani was based on Rodríguez \& Vives, 1984; Lakkis, 1990; Belmonte \& Potenza, 2001; Daly Yahia et al., 2004; Pancucci-Papadopoulou et al., 2005 ; Pane et al., 2005; De Olazalbal et al., 2006 ; Razouls et al., 2009.

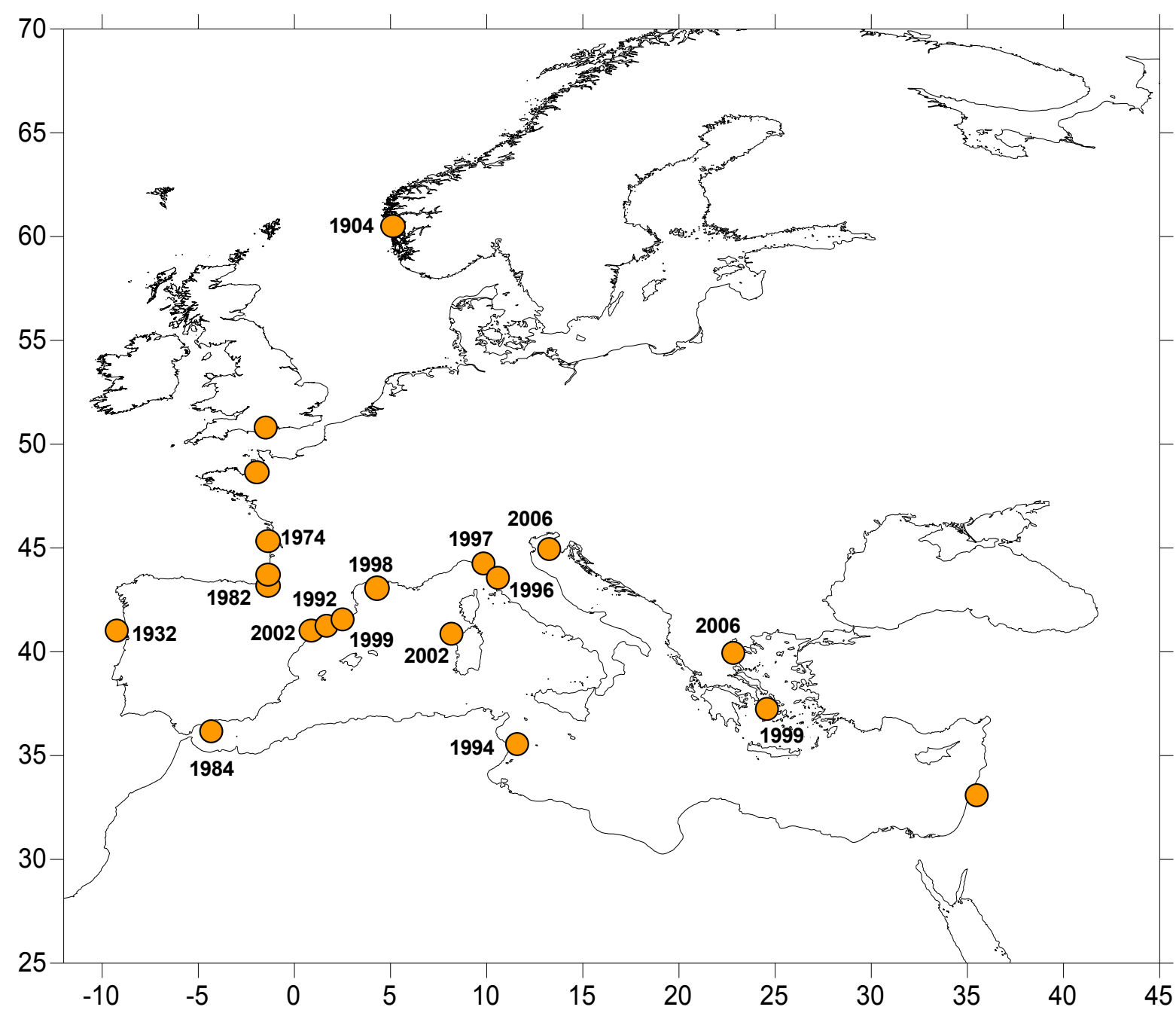


Figure 2. Acartia spp. long term contribution to the total zooplankton abundance (\%) at S1 in Thau lagoon. a- $A$. clausi, b- $A$. discaudata, c- $P$. latisetosa and d- $P$. grani.

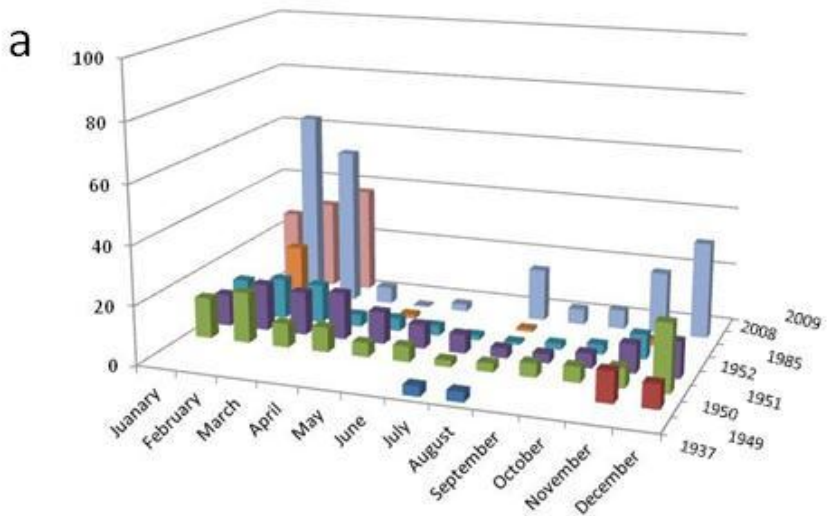

b

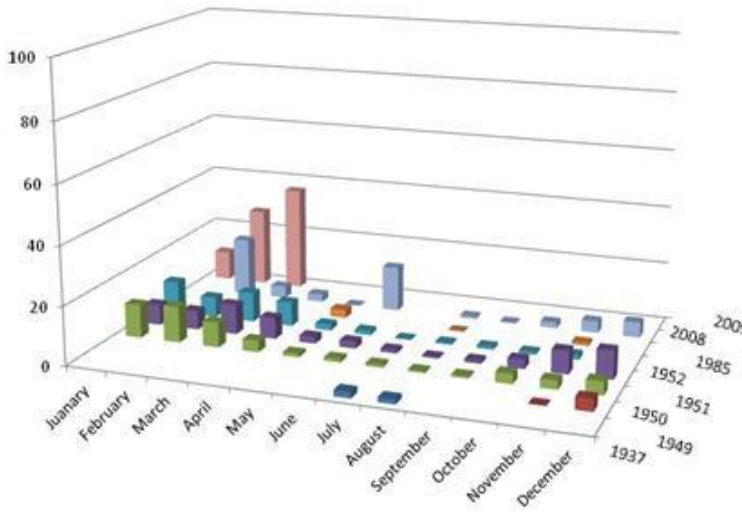

C

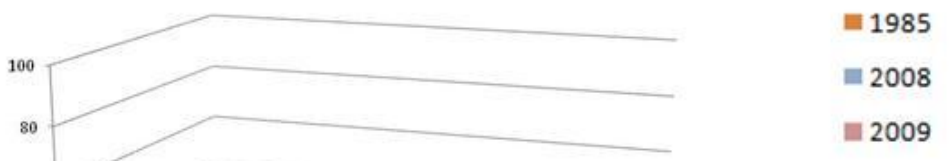

d

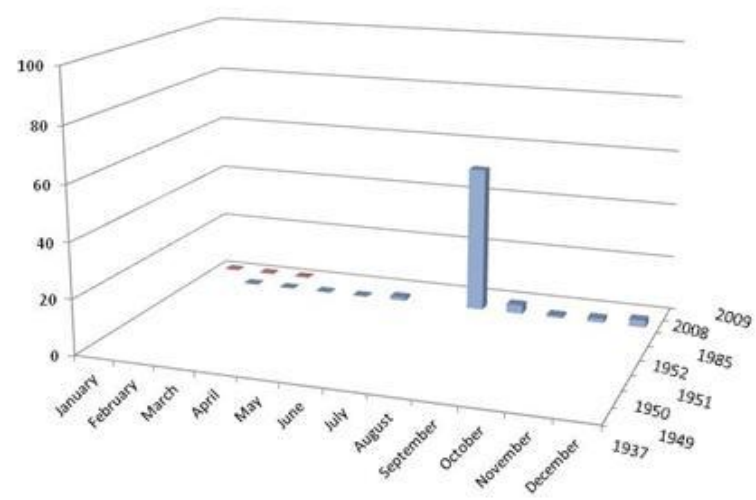


Figure 3. Records of Paracartia grani and several bivalves exploited species in Europe.

:P. grani Oyster farms tomussel farms and : clam farms Sars (1904); Gallo (1981); Rodríguez \& Vives (1984); Lakkis (1990); Belmonte \& Potenza (2001); Daly Yahia et al. (2004); Pancucci-Papadopoulou et al. (2005); Pane et al. (2005); De Olazalbal et al. (2006); Razouls et al. (2009)

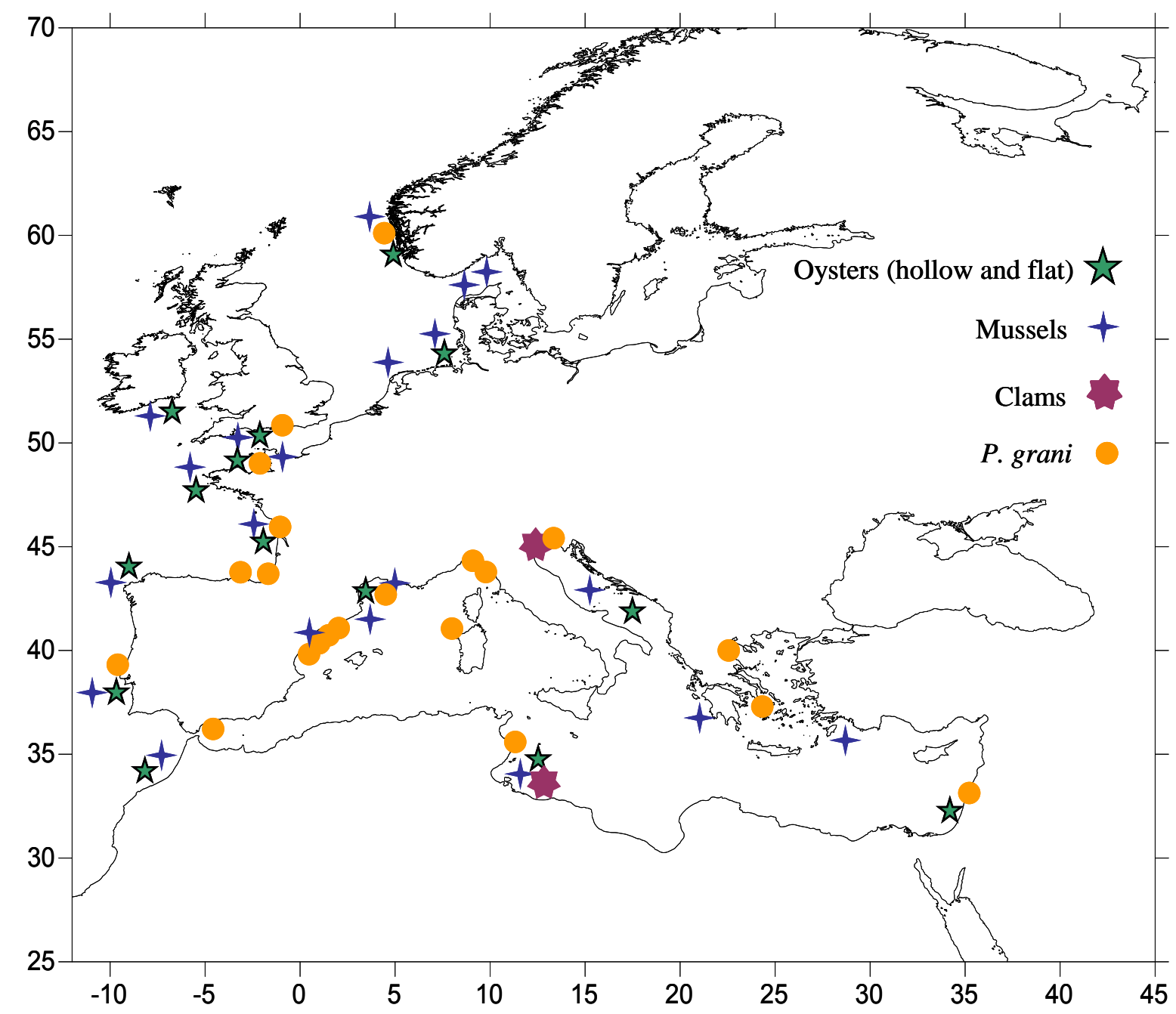

